\title{
The perception of parents and teachers of the influence of yoga on the concentration and co-existing behaviour of learners with attention deficit hyperactivity disorder (ADHD)
}

\author{
KBEART AND AC LESSING ${ }^{2}$
}

\begin{abstract}
This pilot study explores the perception of parents and teachers of the influence of yoga on the concentration and some co-existing behaviour of learners diagnosed with attention deficit hyperactivity disorder (ADHD). The researchers attended to impaired concentration as typical ADHD behaviour and further looked at co-existing phenomena such as aggression, anxiety, and a low self-esteem which the learners may manifest. Semi-structured interviews with parents, teachers and the learners were held. Valuable data, confirming the learners' behaviour manifestation and serving as triangulation, was collected by using a projection test and a self-esteem questionnaire. Interviews and assessments were conducted to analyse the situation initially and again after the yoga intervention. Based on the data collected and analysed, the perception of parents and teachers was that to an extent yoga had a positive influence on the behaviour of learners with ADHD. Although no long-term influence of yoga is determined in this investigation, there is sufficient evidence to suggest that there is potential in using yoga to support learners with ADHD regarding concentration, aggression, anxiety and an improvement in self-esteem.
\end{abstract}

Keywords: ADHD, aggression, anxiety, concentration, self-esteem, yoga

\section{Introduction}

Attention deficit hyperactivity disorder (ADHD) is a medical condition involving brain dysfunction, in which individuals have difficulty controlling impulses, inhibiting their behaviour and sustaining their attention span. ADHD affects many aspects of a child's life and may lead to a variety of educational, behavioural, social and related difficulties (Barkley, 2006; Deidra, Florence, Neilson \& David, 2009; O’Regan, 2005; Salmeron, 2009). 'Children with ADHD are not only more physically active and inattentive than other children, they also have more difficulty responding appropriately and working steadily toward goals' (Woolfolk, 2010:133). The Diagnostic and Statistical Manual of Mental Disorders, Fourth Edition Text Revision (DSM-IV-TR) outlines five criteria for a diagnosis of ADHD: (1) number and

1. Ms K Beart is attached to the Department of Psychology of Education, University of South Africa (Unisa), PO Box 392, Pretoria 0003, South Africa.

2. Prof. Ansie Lessing is attached to the Department of Psychology of Education, University of South Africa (Unisa), PO Box 392, Pretoria 0003, South Africa. Email: lessiac6@unisa.ac.za 
severity of symptoms, (2) age of onset, (3) setting where impairment occurs, (4) clear evidence of impairment, and (5) exclusion of other causes (APA, 2000; Woolfolk, 2010). To be diagnosed with ADHD, the symptoms must have been observed for six months and occur to a degree that is inappropriate for and disruptive to their developmental level. Furthermore, at least some of the symptoms had to be causing difficulties at school or home before the age of seven years (APA, 2000; Curtis, Deutsch, Dube \& McIlvane, 2008; Salmeron, 2009).

The core symptoms of ADHD (hyperactivity, inattentiveness and impulsivity) impede learners' concentration (Aguiar, Eubig \& Schantz, 2010) and may result in underachievement at school (Amiria, Maheria \& Asghar, 2010) and poor relations with peers (Hallowell \& Ratey, 2005; Kranowitz, 2005; McConaughy, Volpe, Antshel \& Gordon, 2011). Academic achievement is influenced by them not completing assignments, leaving their seats repetitively, talking out of turn, losing homework assignments, achieving poor results in tests, exhibiting poor writing skills, and working carelessly (Amiria et al., 2010; Barkley, 2006; DeNisco, Tiago \& Kravitz, 2005). Symptoms of restlessness, intrusiveness, verbal outbursts and the inability to behave in a manner appropriate for a given situation are common manifestations of ADHD and result in learners not only being intrusive, impatient and argumentative but also lacks concentration (Barkley, Edwards, Laneri, Fletcher \& Metevia, 2001; Salmeron, 2009).

The use of medication contributes to an improvement in behaviour of learners with ADHD (Curtis et al., 2008; Woolfolk, 2010), but the behavioural changes do not always have an influence on academic learning and peer relations. Learners with ADHD need more treatment than only medication, which may involve behaviour therapy, counselling and remedial tuition.

Much research is done in the use of yoga to support people with different conditions: autism (Cooper, 2010), general health and sleeping problems (Jaloba, 2011), back pain (Tekur, Singphow, Nagendra \& Raghuram, 2010), schizophrenia (Visceglia \& Lewis, 2011), cancer (Chaoul \& Cohen, 2010), health and wellness (Ross \& Thomas, 2010) performance anxiety and mood disturbance (Khalsa, Shorter, Cope, Wyshak \& Sklar, 2009). Studying these research studies gave rise to the question of whether the use of yoga can support learners with ADHD, thus embedding the central argument that the use of yoga may support learners with ADHD to improve concentration and self-esteem and to reduce anxiety and aggression.

Yoga as a daily exercise programme can improve fitness, strength and flexibility. People who practise yoga correctly every day report that it can promote high levels of overall health, energy and wellbeing (Jaloba, 2011; Ross \& Thomas, 2010; White, 2009). Yoga entails mind-body practices which are techniques designed to enhance the mind's capacity to affect bodily function and symptoms and include relaxation, hypnosis, visual imagery, meditation, biofeedback, cognitive-behavioural therapies, group support, autogenic training, and expressive arts therapies such as art, music or dance (Chaoul \& Cohen, 2010; Cooper, 2010).

Yoga aims at bringing balance and health to the physical, mental, emotional and spiritual dimensions of the individual (Ross \& Thomas, 2010) and comprises eight aspects, including universal ethics, individual ethics, physical postures, breath control, control of the senses, concentration, meditation and bliss. In their study people indicated that they do yoga to gain wellness and improve their state of health.

Children who practise yoga enjoy better health, discipline, temperament, behaviour, concentration, memory and stamina (Ali \& Brar, 2002) and certain poses can be used to help 
with particular needs, such as improving memory and concentration (Dupler \& Odle, 2005). It seems as if the mental component of yoga can clarify and discipline the mind, and yoga practitioners say its benefits can permeate all facets of a person's life and attitude, raising selfesteem and self-understanding.

Hatha yoga is the most widely practised form of yoga in America (White, 2009). It is the branch of yoga that concentrates on physical health and mental wellbeing. Hatha yoga uses bodily postures (asanas), breathing techniques (pranayama) and meditation (dhyana) with the goal of bringing about a sound, healthy body and a clear, inner awareness and peaceful mind. There are nearly 200 Hatha yoga postures, with many variations, which work to make the spine supple and to promote circulation in all organs, glands and tissues. Hatha yoga postures not only stretch and align the body, but also promote balance and flexibility (Clothey, 2006; Dupler \& Odle, 2005; Lesser, 1998; Prakashan, 2000; Sivananda Yoga Vedanta Centre, 1996; Stiles, 2000). Yoga is beneficial to those with ADHD as it helps control anger to a great extent and the use of dynamic postures and breathing techniques successfully calms the nerves and the mind (Hota, 2008).

The positive feedback of people on the use of yoga for health and wellbeing gave rise to the question of whether yoga has the potential to improve the concentration of learners with ADHD and to reduce the co-existing symptoms of aggression, anxiety and low self-esteem. This article reflects on a pilot study of ten purposively selected learners with ADHD with the aim of determining the perception of their parents and teachers of the influence of yoga on their manifestation of poor concentration, anxiety, poor self-esteem and aggression.

\section{Method}

\section{Procedure}

Albeit a pilot study, this preliminary study on the perception of parents and teachers of the behaviour of learners with ADHD may contribute to the body of psycho-educational knowledge. The nature of a pilot study is exploratory and is designed to provide a general understanding of a phenomenon (Reber, Allen \& Reber 2009). In this study it refers to the perception of parents and teachers of the influence of yoga on the concentration and coexisting behaviour of learners diagnosed with ADHD.

This qualitative research followed an interactive mode of inquiry, using an instrumental case study (Leedy \& Ormrod, 2010; McMillan \& Schumacher, 2001) to explore parents', teachers' and learners' perceptions of the influence of yoga on learners with ADHD's manifestations of anxiety, concentration, aggression and self-esteem. Assessments were conducted at two points in time, to contribute to the trustworthiness of the investigation. It was done at the commencement of the yoga intervention as a situation analysis with regard to the different aspects under study and at the completion of the yoga intervention to determine the outcome of the support.

The yoga intervention took place for six weeks and the learners attended classes twice a week for forty minutes at a time. Table 1 provides a summary of the various postures in yoga which address particular aspects of concentration, aggression, anxiety and self-esteem. As children usually love animals many of the yogic postures incorporated in the sessions were based on birds and beasts. 
Table 1. Yoga postures used in the intervention

\begin{tabular}{|c|c|c|}
\hline Aspects & Posture & Benefits \\
\hline \multirow[t]{8}{*}{ 1. Concentration } & The Eagle & $\begin{array}{l}\text { - balances posture } \\
\text { - develops concentration and focus } \\
\text { - nurtures determination and inner conviction } \\
\text { - improves attention span, calms the mind, improves the eye } \\
\text { muscles }\end{array}$ \\
\hline & The Frog & $\begin{array}{l}\text { - gives a quick boost of energy } \\
\text { - helps 'let off some steam' }\end{array}$ \\
\hline & The Crow & $\begin{array}{l}\text { - requires strength, confidence and concentration } \\
\text { - helps one to feel in control and strengthen inner conviction }\end{array}$ \\
\hline & $\begin{array}{l}\text { The Mouse or } \\
\text { 'Child's Pose' }\end{array}$ & $\begin{array}{l}\text { - settles the learner when feeling hyperactive or overtired } \\
\text { - restores energy, calms the mind, and can help induce sleep }\end{array}$ \\
\hline & $\begin{array}{l}\text { Mirror, mirror on } \\
\text { the wall }\end{array}$ & $\begin{array}{l}\text { - builds concentration and co-ordination } \\
\text { - makes children sensitive to the energies of others }\end{array}$ \\
\hline & $\begin{array}{l}\text { Tree Pose, } \\
\text { Mountain Pose } \\
\text { and } \\
\text { The Dancer }\end{array}$ & $\begin{array}{l}\text { - standing poses where concentration is needed to stand } \\
\text { completely }\end{array}$ \\
\hline & $\begin{array}{l}\text { Forward Bend with } \\
\text { Chair }\end{array}$ & $\begin{array}{l}\text { - a relaxing pose that requires no effort and helps to quieten a } \\
\text { busy mind or an aching head }\end{array}$ \\
\hline & The Scorpion & $\begin{array}{l}\text { - aids concentration and balance } \\
\text { - boosts confidence }\end{array}$ \\
\hline \multirow[t]{4}{*}{ 2. Aggression } & The Fish & - improves posture and chases away negative feelings \\
\hline & The Crocodile & $\begin{array}{l}\text { - strengthens the back and gives energy } \\
\text { - helps to release anger and aggression }\end{array}$ \\
\hline & The Blue Whale & $\begin{array}{l}\text { - provides a little 'lift' } \\
\text { - calms one down }\end{array}$ \\
\hline & The Pigeon & - helps to calm an agitated mind \\
\hline \multirow[t]{4}{*}{ 3. Anxiety } & The Tortoise & $\begin{array}{l}\text { - helps one imagine being protected by a strong shell } \\
\text { - helps one feel safe and quiet }\end{array}$ \\
\hline & The Dragonfly & $\begin{array}{l}\text { - helps to develop patience and emotional stability } \\
\text { - induces feelings of emotional calm and quiet before going to } \\
\text { bed }\end{array}$ \\
\hline & $\begin{array}{l}\text { The Sleeping Yogi } \\
\text { or Corpse Pose }\end{array}$ & $\begin{array}{l}\text { - a deep relaxation exercise that can keep the learner relaxed and } \\
\text { centred }\end{array}$ \\
\hline & Calm Me Down & - helps to focus when feeling hyperactive or anxious \\
\hline \multirow[t]{4}{*}{ 4. Self-esteem } & The Camel & $\begin{array}{l}\text { - helps to correct poor or lazy posture } \\
\text { - helps all learners to stand tall and feel proud of who they are }\end{array}$ \\
\hline & The Lion & $\begin{array}{l}\text { - energises the body and mind } \\
\text { - builds self-confidence and improves communication skills } \\
\text { - helps with anxiety }\end{array}$ \\
\hline & The Cobra & $\begin{array}{l}\text { - keeps the spine supple and healthy } \\
\text { - tones the nerves, improving communication between the brain } \\
\text { and body } \\
\text { - helps the learner feel strong and powerful }\end{array}$ \\
\hline & The Warrior & - helps one to feel grounded \\
\hline
\end{tabular}

(Currie, 2002; Gibbs, 2005; Singleton, 2004; Weller, 2007) 
To confirm co-existing behaviour a projective technique (Children's Apperception Test: CAT) and a self-esteem scale (the Lawrence Self-Esteem Questionnaire; LAWSEQ) were completed by the learners during the situation analysis. The assessment was repeated after the yoga intervention of six weeks to serve as triangulation of the findings from the interviews.

One of the researchers, who is familiar to the parents, teachers and learners and is also involved in a therapeutic role at the school, acted as fieldworker to do the assessment of the learners and conducted the interviews. Interviews with the parents and teachers were done to gather information regarding the learners' levels of concentration, anxiety, aggression and self-esteem.

The data was processed and analysed. The steps in the analysis were as follows: organisation of details about the case, categorisation of the data, interpretation of single instances, identification of patterns, synthesising and the determination of trends (Leedy \& Ormrod, 2010; McMillan \& Schumacher, 2001).

The researchers were wary of researcher bias to avoid subjectivity (Johnson \& Christensen, 2004) and strived for a report uncontaminated by personal bias or moral judgments (Smith, 2006). In spite of this precaution, the possibility exists that the outcome of the research could have been contaminated by the authors' ability to intervene (Lindegger, 2002). The researchers are qualified educational psychologists. They also made use of multiple data collection methods and data sources to enhance the trustworthiness of the research. The researchers adhered to the necessary ethical measures in the accumulation of data on using yoga with learners with ADHD (Gay, Mills \& Airasian, 2006; McMillan \& Schumacher, 2006). Clients were informed that they would be participating in research, that participation was voluntary and that they could withdraw from the research at any stage (Strydom, 2005). The fundamental ethical rules that the research should be confidential (Strydom, 2005) and not cause discomfort and harm to the participants (Durrheim, 2002; Schumacher \& McMillan, 1993) were adhered to. We focused on the meaning that the participants attributed to the influence of yoga on concentration and certain co-existing behaviour in learners diagnosed with ADHD. To retain confidentiality the alphabetic letters A to J were used to indicate the various learner participants.

\section{Data collection}

Learners, parents and teachers contributed to a range of data collection procedures, which drew on several sources: learner self-esteem questionnaires (Lawrence Self-Esteem Questionnaire - LAWSEQ), learner projection tests (CAT), parent-rated questionnaires, teacher-rated questionnaires and semi-structured interviews with learners, parents and teachers. Interviews were conducted to obtain rich qualitative descriptions of the life world of the participants with respect to their interpretation of their experiences, opinions, feelings and knowledge (Patton, 2002). The interviews were tape-recorded and transcribed and interpretations of the participants were conducted.

The CAT is a projective personality test used to assess individual variation in children's responses to standardised stimuli presented in the form of pictures of animals (CAT-A) or humans (CAT-H) in common social situations, with regard to personality, level of maturity and, often, psychological health. The CAT-H was used as a projection medium to determine 
possible aspects of anxiety or aggression in the participants during the situation analysis and the CAT-H to assess the outcome of the yoga intervention.

The primary school version of the LAWSEQ was administered to the learners before and after the yoga intervention. The researcher assisted by reading the statements to the learners, but they were given privacy when responding. The questionnaire measures global self-esteem and comprises sixteen items to be answered with yes, no or don't know; a high score on yes indicates a high self-esteem.

\section{Sample}

The study took place in a school for learners with learning difficulties. To recruit participants teachers were asked to refer learners whom they knew were diagnosed by a paediatrician as learners with ADHD, as the information was recorded on the learners' school files. Ten learners were purposely selected on the grounds of the following criteria: the learner must have been a primary school learner at the school and been diagnosed with ADHD. Three teachers and eleven parents were willing to participate in the pilot study and a yoga instructor was willing to assist with the research by presenting a specialised yoga programme for learners with ADHD. The necessary consent and assent forms were signed.

\section{Results and discussion of the findings}

\section{Biographical data of the participants in the case study}

All participating learners were male, of whom seven were nine years old and three were ten years old. With regard to medication and supplements for ADHD, six of the participants were using Ritalin, two were using Concerta, one was not medicated and one was using Eye$\mathrm{Q}$ (see Table 2). All were diagnosed with ADHD at a preschool age by a paediatrician.

\section{Table 2. Biographical details of participants}

\begin{tabular}{|c|c|c|c|c|c|}
\hline Participant & Grade & Age & Age of onset & Diagnosed by & Medication \\
\hline A & 4 & 10 & Preschool & Paediatricians & Ritalin $15 \mathrm{mg}$ 7:00; $10 \mathrm{mg}$ 11:00 \\
\hline $\mathrm{B}$ & 4 & 9 & Preschool & Paediatricians & Ritalin $20 \mathrm{mg}$ LA \\
\hline $\mathrm{C}$ & 4 & 10 & Preschool & Paediatricians & Ritalin $20 \mathrm{mg} \mathrm{LA}$ \\
\hline $\mathrm{D}$ & 4 & 10 & & Paediatricians & $\begin{array}{l}\text { Ritalin } 20 \mathrm{mg} \mathrm{LA} \text { at } 7: 00 ; 15 \mathrm{mg} \text { at } \\
\text { 10:30; } 10 \mathrm{mg} \text { at 14:00. Also Telemol } \\
\text { for anxiety }\end{array}$ \\
\hline $\mathrm{E}$ & 4 & 9 & Preschool & Paediatricians & Ritalin $20 \mathrm{mg}$ LA \\
\hline $\mathrm{F}$ & 4 & 9 & Preschool & Paediatricians & Concerta $36 \mathrm{mg}$ \\
\hline G & 4 & 9 & Preschool & Paediatricians & $\begin{array}{l}\text { Ritalin } 20 \mathrm{mg} \mathrm{LA} \text { at } 7: 00 ; 5 \mathrm{mg} \text { at } \\
11: 30\end{array}$ \\
\hline$\overline{\mathrm{H}}$ & 4 & 9 & Preschool & Paediatricians & Concerta $36 \mathrm{mg}$ \\
\hline I & 4 & 9 & Preschool & Paediatricians & $\begin{array}{l}\text { No medicine; just Eye-Q and Scott's } \\
\text { Emulsion capsules as there had been } \\
\text { morbid thoughts on Ritalin }\end{array}$ \\
\hline $\mathrm{J}$ & 4 & 9 & Preschool & Paediatricians & No medicine \\
\hline
\end{tabular}




\section{Findings on concentration}

It was evident from the initial responses of the participating parents and teachers that the learner participants lacked concentration both at home and in the classroom. This was in spite of the fact that some of them used medication.

Teacher: $C$ is very active and talkative ... he's always jumping around and playing.

It's very hard for him to sit and do his work and he's despondent and negative against it.

Parent: It's impossible to get $H$ to complete his homework. He often blurts things out without thinking.

At the outcome of the yoga intervention participants reported that concentration had improved even if for a short period of time. The following comments were made:

Teacher: I did find them definitely calmer ... almost sort of into themselves.

Participant A:'I used the exercise with the hands to help me focus.

In particular, noticeable improvement was reported in the concentration of participants $\mathrm{C}, \mathrm{D}$, E, G, H and I.

The parent of participant $C$ commented: His homework that he's been bringing home is much better, so the time we have taken for homework has been quicker and he's done things properly and there have been fewer corrections.

\section{Findings on aggression}

The parents of only three learners indicated initially that their children did not show aggression or have anger-related outbursts. Two of the ten learners were indicated as acting out very often. Parents' and teachers' responses during the situation analysis indicated high levels of frustration in all participants.

The responses of the learners of the CAT during the situation analysis confirmed parents' perceptions as it revealed elements of aggression in all the participants' stories. The comments and stories of six of the participants were particularly violent.

\section{Participant F: The kid jumped on bim and kicked bim in the balls and stuck his fingers}

in his eyes... and he died.

With regard to aggression, parents' and teachers' impressions at the outcome of the yoga intervention include some positive comments.

Parent of participant E: He calmed down a lot as regards aggression. Definitely the aggression issues seem to have dissipated in that time.

ADHD often results in frustration, low tolerance, lying, swearing, stealing and blaming others, which are manifestations of aggression (O'Regan, 2005; Rief, 2005). Furthermore, learners with ADHD may overreact and be self-destructive (Chee \& Green, 2004) or show violent outbursts as manifestation of hopelessness (Pauc, 2006). Although some of the learners took medication to support them with their ADHD condition, parents' perception was that the yoga exercises, in combination with the medicine, support them to a greater extent to take control over their aggression. 


\section{Findings on anxiety}

Parents and teachers initially indicated different levels of anxiety in the learners as well as anxiety-related issues. Most of the parents indicated a fear of darkness in their children. These fears were affirmed in the CAT responses.

The boy is feeling very scared because he is afraid of the dark.

He always used to hear these noises in the house.

The responses of the learners for the CAT, after the yoga intervention, provided an indication that the anxiety-related issues might have decreased. Many stories reflected a reason to not be afraid any longer, or that the characters in the story were more able to take control of the situation. For example:

... it was just his parents, not a baddie.

... he was arrested.

Parents and teachers also indicated a decrease in anxiety-related aspects.

I think his anxiety has improved; it's sitting at six on a scale out of ten.

He's $(H)$ been sleeping through lately.

Although Rakel and Faas (2006) contend that relaxation exercises such as meditation, used in yoga, have shown beneficial effects on anxiety, Lehrer, Woolfolk and Sime (2007) indicate that very little research has evaluated yoga treatments specifically for anxiety disorder. This limited investigation indicates a tendency of decreasing anxiety in learners with ADHD.

\section{Findings on self-esteem}

Findings from the situation analysis reveal that learners' levels of self-esteem fluctuated and depended on the specific circumstances. Low self-esteem manifested especially in social situations and with regard to academic ability, and is reflected in the following quotes:

He worries about what others think about him.

He feels he is not good enough.

His self-esteem is very erratic and unrealistic.

He doesn't have confidence.

He is very nervous to answer questions.

His biggest problem is his lack of self-esteem.

According to the pre- and post-results of the LAWSEQ the self-esteem of four of the participants increased after the yoga intervention. The following thick and valuable responses were gained from the interviews:

Participant C: Usually I felt left out because even though I am chosen in something it's

lit I won't pass or anything, but when the yoga was finished it's like I touched the goal lots of times.

\section{Parent: His self-esteem has definitely picked up, absolutely!}

Self-esteem was a particular focus in this investigation as learners with ADHD often have poor self-esteem. They may find it difficult to form and maintain friendships, experience 
learning difficulties and have troublesome interpersonal relationships with family members (Larimer, 2005; O'Regan, 2005). Learners with ADHD often doubt their talents or strengths with the result that they are likely to lose further interest in their studies (Hallowell \& Ratey, 2005) and their self-esteem generally diminishes even further (Young, 2007:58).

The findings of this study are in accordance with existing research. Balanced yoga practice teaches a child to move with relaxed awareness and a sense of grace which culminates in greater acceptance of the self and more confidence in personal actions and speech (Singleton, 2004). The greater inner calmness that results from yoga contributes to the improvement of self-esteem (Seaward, 2006) and provides affirmations to build self-esteem (Jollands, 1998). The learners in this study used the following affirmation in all their yoga practices: 'I am strong and steady; for anything I am ready.'

\section{Summary of the findings with specific reference to the participants suffering from ADHD}

From the responses of the parents, the yoga intervention appears to have had a positive influence on all the participants to a certain degree. These perceptions were confirmed by the results of the post assessment. The perceptions of parents and teachers of the influence of yoga on the children are summarised in Table 3.

Table 3. The perceptions of parents and teachers of the influence of yoga on learners with ADHD

\begin{tabular}{|l|l|}
\hline Participant & Perceived changes \\
\hline A & $\begin{array}{l}\text { Parents: no change; still aggressive } \\
\text { Teachers: less anxious }\end{array}$ \\
\hline B & $\begin{array}{l}\text { Parents: improvement in self-esteem } \\
\text { Teachers: improvement in self-esteem }\end{array}$ \\
\hline C & $\begin{array}{l}\text { Parents: less aggressive, more confident; focuses better on homework } \\
\text { Teachers: lacks concentration }\end{array}$ \\
\hline E & $\begin{array}{l}\text { Parents: no change } \\
\text { Teachers: improvement in behaviour and calmer behaviour }\end{array}$ \\
\hline F & $\begin{array}{l}\text { Parents: less anxious and aggressive } \\
\text { Teachers: improved concentration; less aggression }\end{array}$ \\
\hline G & $\begin{array}{l}\text { Parents: less anxious; more relaxed; concentration did not improve } \\
\text { Teachers: less anxious; more confident; improved self-esteem }\end{array}$ \\
\hline H & $\begin{array}{l}\text { Parents: self-esteem improved; less anxious; fewer aggressive episodes at school and home } \\
\text { Teachers: happier }\end{array}$ \\
\hline I & $\begin{array}{l}\text { Parents: able to finish tasks; more confident; less aggressive } \\
\text { Teachers: less anxious; more in control }\end{array}$ \\
\hline J & $\begin{array}{l}\text { Parents: self-esteem and concentration improved } \\
\text { Teachers: improved self-image }\end{array}$ \\
\hline
\end{tabular}

\section{Conclusion}

This article reflected on using a yoga programme on ten learners with ADHD to improve their behaviour. The aim of the investigation was to determine whether yoga has any potential to improve learners with ADHD's behaviour patterns with regard to concentration 
and co-existing aggression, anxiety and self-esteem. The perception of the parents as well as the teachers was that the yoga programme contributed to an improvement in concentration and self-esteem, and reduced aggression and anxiety in most of the participants during the time of the investigation.

As an exploratory study the application of yoga was limited to only ten learners suffering from ADHD and showing co-existing behaviour in one case study, and no generalisations could be made from the findings. The investigation was not aimed at generalisations of the findings but to determine the perceptions of the participants of the potential of yoga to support learners with ADHD. Although no long-term influence of yoga is determined in this investigation, there is sufficient evidence to suggest that a specialised yoga programme has the potential to support learners with ADHD with regard to concentration and $\mathrm{co}^{-}$ existing aggression, anxiety and the improvement of their self-esteem. It would be worthwhile to conduct further studies of this nature with a larger sample, and a yoga intervention that lasts six months or longer, to really ascertain the lasting influence that yoga may have on the learner with ADHD.

\section{References}

Aguiar, A., Eubig, P.A., \& Schantz, S.L. (2010). Attention deficit/hyperactivity disorder: A focused overview for children's environmental health. Environmental Health Perspectives, 118(12), 1646-1653.

Ali, M., \& Brar, J. (2002). Therapeutic yoga. London, England: Random House.

American Psychiatric Association. (2000). Diagnostic and statistical manual of mental disorders (4th ed., text revision). Washington, DC: Author.

Amiria, A.F., Maheria, M., \& Asghar, M.A. (2010). Attention deficit/hyperactivity disorder in primary school children of Tabriz, North-West Iran. Paediatric and Perinatal Epidemiology, 24, 597-601.

APA see American Psychiatric Association.

Barkley, R.A. (2006). Attention deficit byperactivity disorder: A handbook for diagnosis and treatment $\left(3^{\text {rd }}\right.$ ed.). New York: Guilford Press.

Barkley, R.A., Edwards, G., Laneri, M., Fletcher, K., \& Metevia, L. (2001). Executive functioning, temporal discounting, and sense of time in adolescents with attention deficits hyperactivity disorder and oppositional defiant disorder. Journal of Abnormal Child Psychology, 29, 541-556.

Chaoul, M.A., \& Cohen, L. (2010). Rethinking yoga and the application of yoga in modern medicine. Cross Currents, 60, 144-165.

Chee, K., \& Green, C. (2004). The pocket guide to understanding ADHD. London, England: Vermilion.

Clothey, F.W. (2006). Religion in India: An bistorical introduction. London, England: Routledge.

Cooper, C. (2010). A calming influence. Nursing Standard, 24(50), 24-25.

Currie, B. (2002). 10-minute yoga workouts: Power tone your body from top to toe. London, England: Thorsons. 
Curtis, K., Deutsch,C.K., Dube, W.V., \& McIlvane, W.J. (2008). Attention deficits, attention-deficit hyperactivity disorder, and intellectual disabilities. Developmental Disabilities

Research Reviews, 14, 285-292.

Deidra, J.Y., Florence, L., Neilson, C.M., \& David, A.H. (2009). Attention deficit hyperactivity disorder: A Rasch analysis of the SWAN rating scale. Child Psychiatry and Human Development, 40, 543-559.

DeNisco, S., Tiago, C., \& Kravitz, C. (2005). Evaluation and treatment of

pediatric ADHD. The Nurse Practitioner, 30(8), 14-23.

Dupler, D., \& Odle, T.G. (2005). 'Hatha Yoga'. The Gale Encyclopedia of Alternative Medicine. Edited by Jacqueline L Longe (2nd ed.). Detroit: Gale. 4 vols. Updated July 1, 2006. Retrieved from: http://www.galenet.galegroup.com [Accessed 8 September 2008].

Durrheim, K. (2002). Putting design into practice: Writing and evaluating research proposals. In M.Terre Blance \& K. Durrheim (Eds.), Research in practice: Applied methods for the Social Sciences (54-71). Cape Town: UCT Press.

Gay, L.R., Mills, G.E. \& Airasian, P. (2006). Educational research: Competencies for analysis and applications (8th ed.). Upper Saddle River, NJ: Pearson.

Gibbs, B. (2005). Yoga for children. London, England: Anness.

Hallowell, E.M., \& Ratey, J.J. (2005). Delivered from distraction: Getting the most out of life with attention deficit disorder. London, England: Ballantine.

Hota, B. (2008). Yoga for school children. New Delhi, India: Rupa.

Jaloba, A. (2011). A spiritual workout. Nursing Standard, 25(48), 20-21.

Johnson, B., \& Christensen, L. (2004). Educational research: Quantitative, qualitative and mixed approaches. Boston, MA: Pearson Education.

Jollands, B. (1998). Instant calm: Natural ways to reduce stress. New York: Lorenz Books, Anness.

Khalsa, S.B.S., Shorter, S.M., Cope, S., Wyshak, G., \& Sklar, E. (2009). Yoga ameliorates performance anxiety and mood disturbance in young professional musicians. Applied Psychophysiology Biofeedback, 9(34), 279-289.

Kranowitz, C.S. (2005). The out-of-sync child: Recognising and coping with sensory processing disorder. New York: The Berkley.

Larimer, M.P. (2005). Attention deficit byperactivity disorder (ADHD) research developments. New York: Nova Science.

Leedy, P.D., \& Ormrod, J.E. (2010). Practical research. Upper Saddle River, NJ: Pearson Education.

Lehrer, P.M., Woolfolk, R.L., \& Sime, W.E. (2007). Principles and practice of stress management. New York: The Guilford.

Lesser, R. (1998). The yoga manual. New York: Todtri. 
Lindegger, G. (2002). Research methods in clinical research. In M. Terre Blance, \& K. Durrheim (Eds.), Research in Practice: Applied methods for the Social Sciences (251-268). Cape Town: UCT.

McConaughy, S.H., Volpe, R.J., Antshel, K.M., \& Gordon, M. (2011). Academic and social impairments of elementary school children with attention deficit hyperactivity disorder. School Psychology Review, 40(2), 200-225.

McMillan, J.H., \& Schumacher, S. (2001). Research in education: A conceptual introduction (5th ed.). New York: Addison Wesley Longman.

McMillan, J.H. \& Schumacher, S. (2006). Research in education: Evidence-based inquiry (6th ed.). New York: Pearson.

O'Regan, F.J. (2005). ADHD. London, England: Continuum International.

Patton, M.Q. (2002). Qualitative research and evaluation methods. Thousand Oaks, CA: Sage.

Pauc, R. (2006). Is that my child? Exploding the myths of dyspraxia, dyslexia, Tourette's syndrome of childhood, ADD, ADHD and OCD. London, England: Virgin Books.

Prakashan, V.K. (2000). Yoga: Asanas, panayama, mudras, kriyas. Chennai, India: Vivekananda Kendra Prakashan Trust.

Rakel, D., \& Faas, N. (2006). Complementary medicine in clinical practice. Boston, MA: Jones $\&$ Bartlett.

Reber, A.S., Allen, R., \& Reber, E.S. (2009). The Penguin Dictionary of Psychology. (4 ${ }^{\text {th }}$ ed.) London: Penguin Books.

Rief, S.F. (2005). How to reach and teach children with ADD/ADHD. San Francisco, CA: Jossey-Bass.

Ross, A., \& Thomas, S. (2010). The health benefits of yoga and exercise: A review of comparison studies. The Journal of Alternative and Complementary Medicine, 16(1), 312.

Salmeron, P.A. (2009). Childhood and adolescent attention-deficit hyperactivity disorder: Diagnosis, clinical practice guidelines, and social implications. Journal of the American Academy of Nurse Practitioners, 21(2009), 488-497.

Schumacher, S., \& McMillan, J.H. (1993). Research in education: A conceptual introduction. (3rd ed.). New York: Harper Collins College Publishers.

Seaward, B.L. (2006). Essentials of managing stress. Sudbury, Canada: Jones \& Bartlett.

Singleton, M. (2004). Yoga for you and your child. London, England: Duncan Baird.

Sivananda Yoga Vedanta Centre. (1996). Yoga: Mind and body. London, England: Dorling Kindersley.

Smith, S. (2006). Encouraging the use of reflexivity in the writing up of qualitative research. International Journal of Therapy and Rehabilitation, 13, 209-215.

Stiles, M. (2000). Structural yoga therapy: Adapting to the individual. Boston, MA: Red Wheel/Weiser.

Strydom, H. (2005). Ethical aspects of research in the social sciences and human service professions. In A.S. de Vos, H. Strydom, C.B. Fouché, \& C.S.L. Delport (Eds.), 
Research at grassroots for the social sciences and human service professions (3rd ed.), 56-85. Pretoria: Van Schaik.

Tekur, P., Singphow, C., Nagendra, H.R. \& Raghuram, N. (2010). Effect of short-term intensive yoga program on pain, functional disability, and spinal flexibility in chronic low back pain: A randomized control study. The Journal of Alternative and Complementary Medicine, 14(6), 637-644.

Visceglia, E., \& Lewis, S. (2011). Yoga therapy as an adjunctive treatment for schizophrenia: A randomized, controlled pilot study. Journal of Alternative and Complementary Medicine, 17(7), 601-607.

Weller, S. (2007). Healing yoga: A practical approach to healing common ailments with yoga. London, England: Collins \& Brown.

White, L.S. (2009). Yoga for Children. Pediatric Nursing, 35(5), 279-296.

Woolfolk, A. (2010). Educational psychology. Upper Saddle River, NJ: Pearson Education.

Young, J.L. (2007). ADHD grown up: A guide to adolescent and adult ADHD. New York: WW Norton. 